\title{
Impact of a new condensed toluene mechanism on air quality model predictions in the US
}

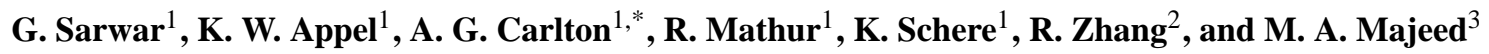 \\ ${ }^{1}$ Atmospheric Modeling and Analysis Division, National Exposure Research Laboratory, Office of Research and \\ Development, US Environmental Protection Agency, RTP, NC 27711, USA \\ ${ }^{2}$ Department of Mathematics, The Hong Kong University of Science \& Technology, Clear Water Bay, Kowloon, \\ Hong Kong, China \\ ${ }^{3}$ Delaware Department of Natural Resources \& Environmental Control, New Castle, DE, USA \\ "now at: Department of Environmental Sciences, Rutgers University, New Brunswick, NJ, USA
}

Received: 23 November 2010 - Published in Geosci. Model Dev. Discuss.: 6 December 2010

Revised: 24 February 2011 - Accepted: 1 March 2011 - Published: 14 March 2011

\begin{abstract}
A new condensed toluene mechanism is incorporated into the Community Multiscale Air Quality Modeling system. Model simulations are performed using the CB05 chemical mechanism containing the existing (base) and the new toluene mechanism for the western and eastern US for a summer month. With current estimates of tropospheric emission burden, the new toluene mechanism increases monthly mean daily maximum 8 -h ozone by $1.0-3.0 \mathrm{ppbv}$ in Los Angeles, Portland, Seattle, Chicago, Cleveland, northeastern US, and Detroit compared to that with the base toluene chemistry. It reduces model mean bias for ozone at elevated observed ozone concentrations. While the new mechanism increases predicted ozone, it does not enhance ozone production efficiency. A sensitivity study suggests that it can further enhance ozone if elevated toluene emissions are present. While it increases in-cloud secondary organic aerosol substantially, its impact on total fine particle mass concentration is small.
\end{abstract}

\section{Introduction}

Toluene is an important aromatic compound that can affect ozone $\left(\mathrm{O}_{3}\right)$ and secondary organic aerosol (SOA) in the atmosphere. However, there is currently a great deal of uncertainty related to toluene chemistry (Calvert et al., 2002). Different chemical mechanisms use different approximations for toluene reactions that can result in different ozone predictions. For example, Faraji et al. (2008) used the Carbon Bond IV (CB-IV) (Gery et al., 1989) and the Statewide Air Pollution Research Center (SAPRC-99) chemical mechanisms (Carter, 2000) for Houston and reported that $\mathrm{O}_{3}$ predictions differed by as much as $40 \mathrm{ppbv}$. The authors attributed the difference in predicted concentrations mostly due to the differences in aromatic chemistry in the two mechanisms. Yarwood et al. (2005) extended the CB-IV mechanism into an updated Carbon Bond (CB05) mechanism consisting of 156 chemical reactions involving 52 chemical species. Sarwar et al. (2008) evaluated the impact of the CB05 mechanism on model predictions in the US and reported that the use of $\mathrm{CB} 05$ increases predicted $\mathrm{O}_{3}$ compared to those with the CB-IV. Toluene chemistry in CB05 was retained from the CB-IV chemical mechanism. Recently, Whitten et al. (2010) proposed a new condensed toluene mechanism for CB05 mechanism. They performed simulations using the existing CB05 mechanism as well as the new CB05 mechanism containing the new condensed toluene mechanism for 38 environmental chamber experiments involving different combinations of toluene and oxides of nitrogen $\left(\mathrm{NO}_{\mathrm{x}}\right)$. They used four different performance metrics to compare model predictions with chamber data: maximum $\mathrm{O}_{3}$, maximum $\Delta\left(\mathrm{NO}-\mathrm{O}_{3}\right), \mathrm{NO}_{\mathrm{x}}$ crossover time, and cresol concentrations $(\mathrm{NO}=$ nitric oxide). The new toluene mechanism provided better results than the existing toluene chemistry in simulating chamber data. This study examines the impact of the new condensed toluene mechanism on air quality model predictions in the US.

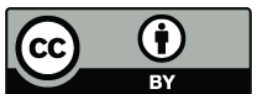

Correspondence to: G. Sarwar

(sarwar.golam@epa.gov)

Published by Copernicus Publications on behalf of the European Geosciences Union. 


\section{Methodology}

\subsection{Model description}

The study uses the Community Multiscale Air Quality (CMAQ) modeling system (version 4.7) (Binkowski and Roselle, 2003; Byun and Schere, 2006) to simulate air quality. Evaluations for the CMAQ modeling system have recently been conducted by comparing model predictions to measured ambient pollutants (Eder and Yu, 2006; Appel et al., 2007; Foley et al., 2010). The CMAQ model has considerable skill in simulating $\mathrm{O}_{3}$ mixing ratios in the atmosphere. For example, CMAQv4.7 predicts 8-h maximum $\mathrm{O}_{3}$ with a normalized median bias of $6.9 \%$ and a normalized median error of 14.5\% in August 2006 (Foley et al., 2010). Two modeling domains are used for the study. One domain focuses on the western US and consists of $213 \times 192$ horizontal grid-cells while the other domain focuses on the eastern US and consists of $213 \times 188$ horizontal grid-cells with a $12-\mathrm{km}$ resolution. Each model contains 14 vertical layers of variable thickness between the surface and $100 \mathrm{mb}$ with a surface layer thickness of approximately $36 \mathrm{~m}$. Model simulations are performed for the eastern US for July 2001 and for the western US for July 2002. While the modeling time periods used for the western and eastern US domains are different, findings presented herein are not likely to change if same time period is used for the both domains.

The CMAQ chemical transport model is configured to use the mass continuity scheme to describe advection processes, the Asymmetric Convective Model Version 2 (ACM2) (Pleim, 2007) to describe vertical diffusion processes, the multiscale method to describe horizontal diffusion processes, and an adaptation of the ACM algorithm for convective cloud mixing. Aqueous chemistry, aerosol processes, and dry/wet deposition are included. The meteorological driver for the CMAQ modeling system is the PSU/NCAR MM5 system (version 3.5) (Grell et al., 1994). Initial and boundary conditions for this study are obtained from CMAQ model results of a larger modeling domain.

Each domain is first simulated using the CB05 chemical mechanism containing existing toluene chemistry (CB05Base) (Yarwood et al., 2005) and then using the CB05 chemical mechanism containing the new toluene chemistry (CB05TU) (Whitten et al., 2010). The difference in modeling results obtained with the two model simulations are attributed to the differences in toluene chemistry.

The CMAQ modeling system currently provides three different gas-phase chemistry solvers: the Sparse-Matrix Vectorized Gear Algorithm solver, the Rosenbrock solver, and the Euler Backward Iterative (EBI) solver. The EBI solver is dependent on chemical mechanism which necessitates the development of a new EBI solver for each new mechanism. The Rosenbrock and the Sparse-Matrix Vectorized Gear Algorithm solvers are generalized solvers that can usually be used for any chemical mechanisms without requiring any

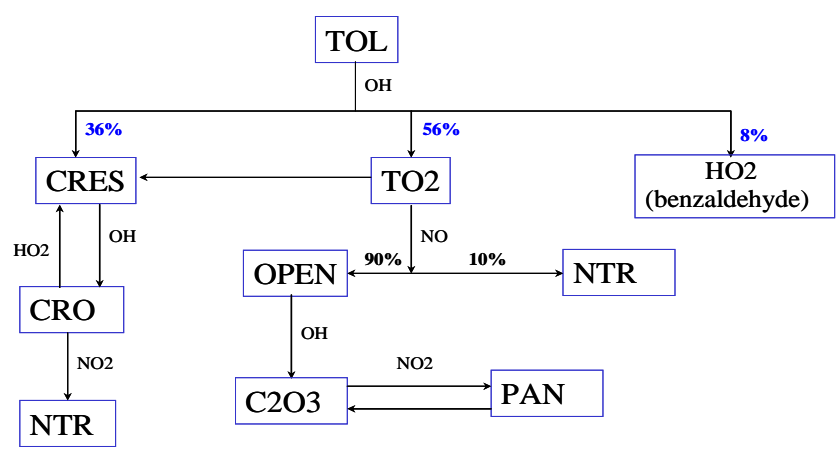

Fig. 1. A simplified schematic diagram of toluene chemistry in CB05-Base mechanism.

changes. The Sparse-Matrix Vectorized Gear Algorithm solver is the slowest but the most accurate among the three solvers. The Rosenbrock solver is faster than the SparseMatrix Vectorized Gear Algorithm solver and was used for this study. The use of CB05-TU increases computational time of the model by 3-6\% compared to the CB05-Base.

\subsection{Toluene chemistry}

Toluene chemistry in CB05-Base contains 10 chemical reactions involving 5 chemical species. A simplified schematic diagram of the toluene chemistry in CB05-Base is presented in Fig. 1. Reaction of toluene (TOL) with hydroxyl radical $(\mathrm{OH})$ proceeds via three different channels: $36 \%$ of the reaction produces cresol (CRES), $56 \%$ produces a bicyclic peroxy radical (TO2), and $8 \%$ produces benzaldehyde. Contribution of benzaldehyde to $\mathrm{O}_{3}$ is negligible; thus, it is not further retained in $\mathrm{CB} 05$. TO2 reacts with $\mathrm{NO}$ to produce organic nitrate (NTR) and a ring-opening product (OPEN) or breaks down to produce CRES. OPEN reacts with $\mathrm{OH}$ to form acetyl peroxy radical $\left(\mathrm{C}_{2} \mathrm{O}_{3}\right)$, which subsequently produces peroxy acetyl nitrate (PAN) via reaction with nitrogen dioxide $\left(\mathrm{NO}_{2}\right)$. During daytime, CRES reacts with $\mathrm{OH}$ to produce methyl phenoxy radical (CRO), which produces NTR via reaction with $\mathrm{NO}_{2}$.

Whitten et al. (2010) describe the detailed chemistry of $\mathrm{CB} 05-\mathrm{TU}$ containing 26 chemical reactions involving 13 species for toluene oxidation and provide a simplified schematic diagram for the chemistry (see Fig. 3 in the reference). Reaction of toluene with $\mathrm{OH}$ proceeds via four different channels: $18 \%$ of the reaction produces CRES, $65 \%$ produces $\mathrm{TO} 2,10 \%$ produces benzaldehyde, and $7 \%$ produces $\mathrm{OH}$. TO2 reacts with NO to produce NTR, OPEN, and methyl glyoxal. OPEN reacts with $\mathrm{OH}$ to form a peroxyacyl radical (OPO3), which leads to an organic PAN (OPAN) via reaction with $\mathrm{NO}_{2}$. During daytime, CRES reacts with $\mathrm{OH}$ to generate $\mathrm{CRO}$, which produces nitro-cresol $(\mathrm{CRON})$ via reaction with $\mathrm{NO}_{2}$. CRON reacts with $\mathrm{OH}$ and leads to an 
alkoxy radical (CRNO) which further reacts with $\mathrm{NO}_{2}$ yielding NTR.

The impact of the revised toluene mechanism on photochemistry and $\mathrm{O}_{3}$ production can be best illustrated by the following reactions:

$$
\begin{aligned}
& \mathrm{HO}_{2}+\mathrm{NO} \rightarrow \mathrm{OH}+\mathrm{NO}_{2} \\
& \mathrm{NO}_{2}+h v \rightarrow \mathrm{NO}+\mathrm{O}\left({ }^{3} \mathrm{P}\right) \\
& \mathrm{O}\left({ }^{3} \mathrm{P}\right)+\mathrm{O}_{2} \rightarrow \mathrm{O}_{3} \\
& \left.\mathrm{HO}_{2}+\mathrm{O}_{2} \rightarrow \mathrm{OH}+\mathrm{O}_{3} \quad \text { (net result of } 1 \text { to } 3\right) \\
& \mathrm{RO}_{2}+\mathrm{NO} \rightarrow \mathrm{RO}+\mathrm{NO}_{2}
\end{aligned}
$$

where $\mathrm{HO}_{2}=$ hydroperoxy radical, $\mathrm{RO}_{2}=$ organic peroxy radical, and $\mathrm{O}\left({ }^{3} \mathrm{P}\right)=$ oxygen atom (triplet), $\mathrm{O}_{2}=$ oxygen .

The reaction of $\mathrm{NO}$ with $\mathrm{HO}_{2}$ converts $\mathrm{NO}$ into $\mathrm{NO}_{2}$ and causes an increase in $\mathrm{O}_{3}$ when $\mathrm{NO}_{2}$ is photolyzed according to Reactions (1-3) (Finlayson-Pitts and Pitts, 2000). The reaction of $\mathrm{NO}$ with $\mathrm{RO}_{2}$ also converts $\mathrm{NO}$ into $\mathrm{NO}_{2}$ and causes an increase in $\mathrm{O}_{3}$ when $\mathrm{NO}_{2}$ is photolyzed (Reaction 4) (Finlayson-Pitts and Pitts, 2000). CB05-TU enhances $\mathrm{HO}_{2}$ and $\mathrm{RO}_{2}$ directly as well as indirectly through an increase in $\mathrm{OH}$ and its subsequent reactions with volatile organic compounds (VOC). If sufficient toluene is present, the new condensed toluene mechanism can enhance $\mathrm{HO}_{2}$ and $\mathrm{RO}_{2}$, and subsequently $\mathrm{O}_{3}$. Since CB05-TU enhances $\mathrm{OH}$, it can also affect other pollutants.

\subsection{Emissions}

Toluene is primarily emitted from anthropogenic sources, although some studies (Heiden et al., 1999 and White et al., 2009) suggest that biogenic sources can also potentially emit toluene. Anthropogenic toluene sources include industrial processes involving production of toluene, solvent usage, surface coating operations, printing and publishing industries, automotive exhaust emissions, gasoline storage and distribution facilities (USEPA, 1994). Heiden et al. (1999) conducted laboratory and field experiments, and reported the presence of toluene emissions from sunflowers and pine trees. They suggested that plants under stress can emit more toluene than plants without stress. White et al. (2009) recently reported that alfalfa and pine trees can emit toluene and suggested that biogenic sources in northern New England in the US can emit as much as $13 \%$ of the total anthropogenic toluene emissions. Toluene emissions from biogenic sources are generally low and not included in biogenic emissions models such as the Biogenic Emissions Inventory System (BEIS). In this study, we use the BEIS (version 3.13) for estimating biogenic emissions (Schwede et al., 2005); as such toluene emissions from biogenic sources are not included.

Anthropogenic emissions are derived from the $2002 \mathrm{Na}-$ tional Emissions Inventory (NEI) for the western US and the

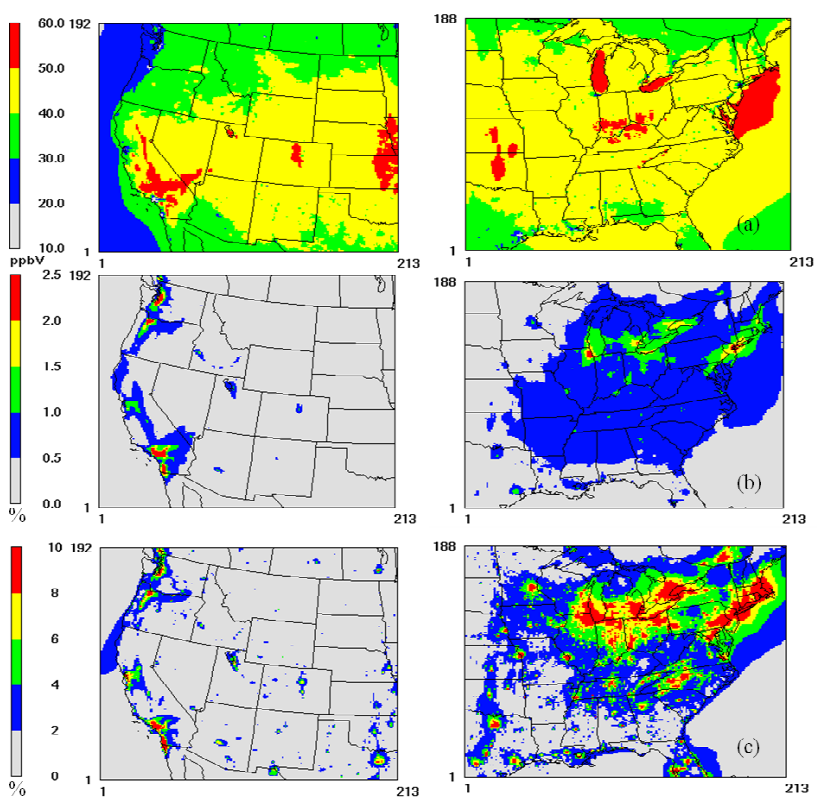

Fig. 2. (a) Monthly mean $\mathrm{O}_{3}$ with $\mathrm{CB} 05-\mathrm{Base}$ (b) percent increases in mean $\mathrm{O}_{3}$ between $\mathrm{CB} 05-\mathrm{TU}$ and $\mathrm{CB} 05$-Base (c) toluene/VOC ratio

2001 NEI for the eastern US. Total toluene emissions in the western US are lower than those in the eastern US. Typical summertime daily toluene emissions in the western US are about $30 \%$ of those in the eastern US. Mobile source sector is the major contributor to toluene emissions burden. On-road and non-road mobile sources collectively contribute $44 \%$ and $32 \%$ of the total toluene emissions in the western and eastern US, respectively. Toluene emissions in urban areas are higher than those in rural areas.

\section{Results and discussion}

\subsection{Impact on $\mathrm{O}_{3}$ and selected gaseous species}

Predicted monthly mean $\mathrm{O}_{3}$ with $\mathrm{CB} 05$-Base and the percent increases in $\mathrm{O}_{3}$ between CB05-TU and CB05-Base are shown in Fig. 2. Mean $\mathrm{O}_{3}$ concentrations of greater than $40 \mathrm{ppbv}$ are predicted over most areas in the western and eastern US. CB05-TU increases mean $\mathrm{O}_{3}$ in three large areas in the western US and three large areas in the eastern US by $2 \%$ or more: Los Angeles; Portland; Seattle; Chicago and the surrounding area; the Lake Erie area including Detriot, Cleveland, Toronto; and the northeastern US coast. Additionally, it increases mean $\mathrm{O}_{3}$ by more than $0.5 \%$ in some areas in the western US and over a large area in the eastern US. Mean toluene/VOC ratios are also shown in the figure. Toluene/ $\mathrm{VOC}$ ratios are greater in urban areas than in rural areas. Enhancements in $\mathrm{O}_{3}$ levels coincided with greater toluene/VOC ratios. 

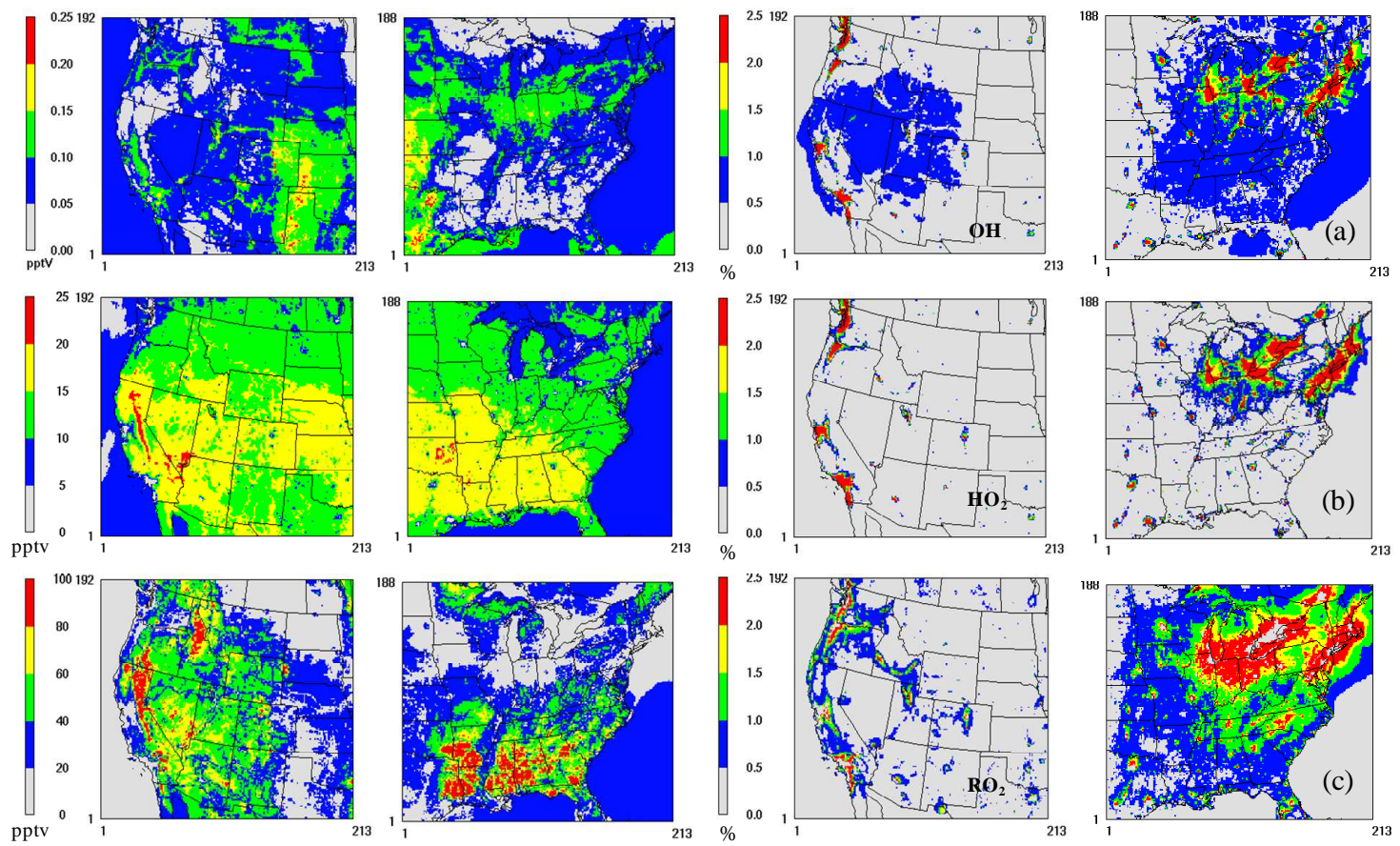

Fig. 3. (a) Monthly mean $\mathrm{OH}$ with $\mathrm{CB} 05-\mathrm{Base}$ and percent increases in mean $\mathrm{OH}$ between $\mathrm{CB} 05-\mathrm{TU}$ and $\mathrm{CB}_{05}-\mathrm{Base}(\mathbf{b})$ mean $\mathrm{HO}_{2}$ with CB05-Base and percent increases in mean $\mathrm{HO}_{2}$ between $\mathrm{CB} 05-\mathrm{TU}$ and $\mathrm{CB} 05$-Base (c) mean $\mathrm{RO}_{2}$ with CB05-Base and percent increases in mean $\mathrm{RO}_{2}$ between $\mathrm{CB} 05-\mathrm{TU}$ and $\mathrm{CB} 05-\mathrm{Base}$. In each row, the first two plots represent mean values (pptv) and the last two plots represent percent changes $(\%)$.

Monthly mean $\mathrm{OH}, \mathrm{HO}_{2}$, and $\mathrm{RO}_{2}$ with $\mathrm{CB} 05$-Base and the percent increases in mean $\mathrm{OH}, \mathrm{HO}_{2}$, and $\mathrm{RO}_{2}$ between the two mechanisms are shown in Fig. 3. Mean $\mathrm{OH}$ concentrations over $0.1 \mathrm{pptv}$ are predicted in many areas in both domains. CB05-TU increases mean $\mathrm{OH}$ by more than $1 \%$ in many areas in the eastern US as well as in isolated areas in the western US. Mean $\mathrm{HO}_{2}$ mixing ratios of over $10.0 \mathrm{pptv}$ are predicted in most areas in the western as well as the eastern US. CB05-TU increases mean $\mathrm{HO}_{2}$ by more than $2 \%$ in Los Angeles, Portland, Seattle, Chicago and the surrounding area, the Lake Erie and the surrounding area, northeastern US coast, and some other smaller areas. Mean $\mathrm{RO}_{2}$ mixing ratios over $40 \mathrm{pptv}$ are predicted in a large part of the western US as well as the southeastern US. CB05-TU increases mean $\mathrm{RO}_{2}$ by more than $2 \%$ in coastal states and some smaller areas in the western US and over large areas in northeastern US and smaller areas in eastern US. Generally, larger changes in mean $\mathrm{OH}, \mathrm{HO}_{2}$, and $\mathrm{RO}_{2}$ occur in areas with larger $\mathrm{O}_{3}$ changes. Enhanced $\mathrm{HO}_{2}$ and $\mathrm{RO}_{2}$ increase $\mathrm{O}_{3}$ via Reactions (1-4).

Monthly mean (daytime) $\mathrm{NO}_{\mathrm{x}}$ reaction products $\left(\mathrm{NO}_{\mathrm{z}}=\mathrm{NO}_{\mathrm{y}}-\mathrm{NO}_{\mathrm{x}}\right)$ with $\mathrm{CB} 05-\mathrm{Base}$ and the percent increases in $\mathrm{NO}_{z}$ between $\mathrm{CB} 05-\mathrm{TU}$ and $\mathrm{CB} 05$-Base are shown in Fig. 4. Relatively high $\mathrm{NO}_{\mathrm{z}}$ values $(>3.0 \mathrm{ppbv})$ are predicted over a large area in the eastern US while such levels are predicted only over scattered areas in the
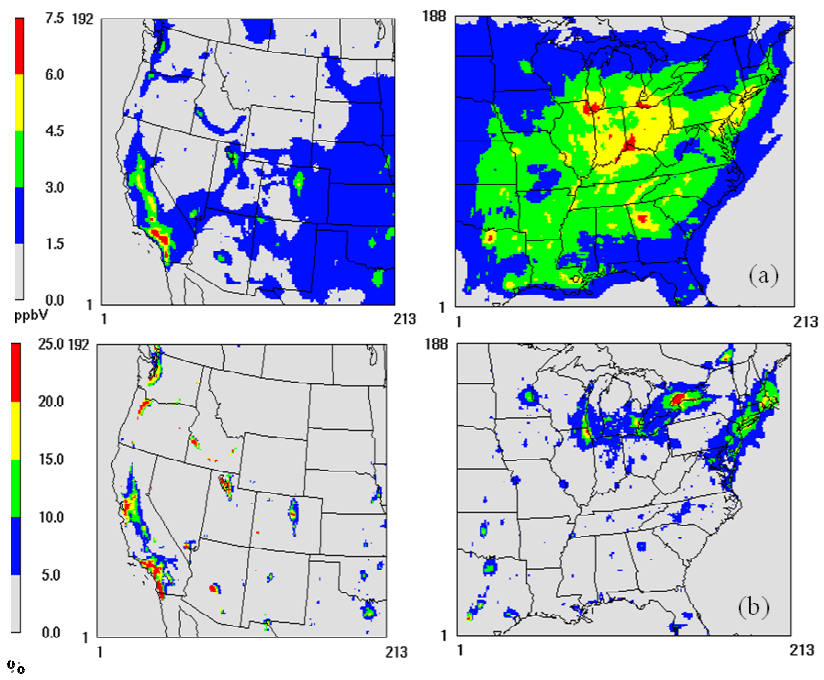

Fig. 4. (a) Monthly mean (daytime) $\mathrm{NO}_{\mathrm{z}}$ with $\mathrm{CB} 05-\mathrm{Base}$ (b) percent increases in mean $\mathrm{NO}_{\mathrm{Z}}$ between $\mathrm{CB} 05-\mathrm{TU}$ and CB05-Base.

western US. CB05-TU increases $\mathrm{NO}_{\mathrm{z}}$ both in the western and eastern US in the same areas that it increases $\mathrm{O}_{3}$. The primary reason for the increase in $\mathrm{NO}_{\mathrm{z}}$ is daytime nitric acid $\left(\mathrm{HNO}_{3}\right)$ production via the reaction: $\mathrm{NO}_{2}+\mathrm{OH}=\mathrm{HNO}_{3}$. CB05-TU enhances $\mathrm{OH}$, thus produces more daytime $\mathrm{HNO}_{3}$ and increases $\mathrm{NO}_{\mathrm{z}}$. 

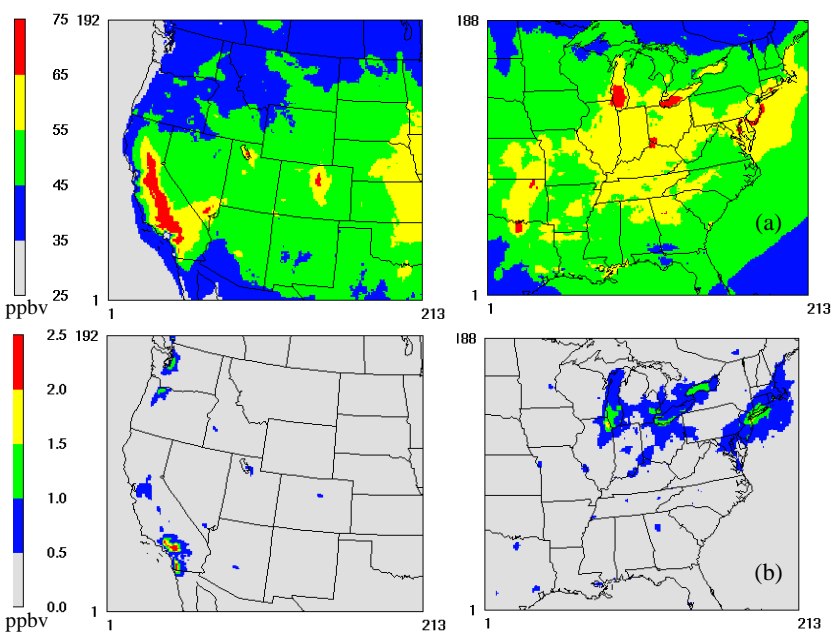

Fig. 5. (a) Monthly mean daily 8-h maximum $\mathrm{O}_{3}$ with $\mathrm{CB} 05-\mathrm{B}$ ase (b) absolute increases in mean daily 8 -h maximum $\mathrm{O}_{3}$ between CB05-TU and CB05-Base.

\subsection{Impact on daily maximum $8-\mathrm{h} \mathrm{O}_{3}$}

Monthly mean daily 8 -h maximum $\mathrm{O}_{3}$ with $\mathrm{CB} 05$-Base and increases in mean 8-h $\mathrm{O}_{3}$ between $\mathrm{CB} 05-\mathrm{TU}$ and CB05-Base are shown in Fig. 5. Elevated levels of 8-h $\mathrm{O}_{3}(>55 \mathrm{ppbv})$ are predicted over only a small area in the western US while similar levels are predicted over a large area in the eastern US. CB05-TU increases monthly mean 8- $\mathrm{h} \mathrm{O}_{3}$ by a maximum of $2.8 \mathrm{ppbv}$ in Los Angeles, 1.5 ppbv in Portland, $1.5 \mathrm{ppbv}$ in Seattle, $2.0 \mathrm{ppbv}$ in Chicago, $1.9 \mathrm{ppbv}$ in Cleveland, $1.7 \mathrm{ppbv}$ in northeastern US, and $1.3 \mathrm{ppbv}$ in Detroit compared to those obtained with the CB05-Base. CB05-TU also increases mean $8-\mathrm{h} \mathrm{O}_{3}$ by 0.5 ppbv or more in several other areas.

Day-to-day variation of the increases in daily 8-h maximum $\mathrm{O}_{3}$ for Los Angeles, Portland, Seattle, Chicago, New York, and Detroit is presented in Fig. 6. For each area, changes in daily 8-h maximum $\mathrm{O}_{3}$ between CB05-TU and CB05-Base vary from day to day. While increases are relatively high (5-10 ppbv) on some days, increases are modest on many other days. In Los Angeles, $\mathrm{O}_{3}$ increases occur on most days while increases in $\mathrm{O}_{3}$ in Portland and Seattle occur on fewer days. Increases in Chicago and New York are comparable, while increases in Detroit are lower than those in Chicago or New York. While the day-to-day variation in toluene emissions is relatively small, the variation in meteorology affects toluene concentrations and subsequent atmospheric chemistry. Generally, greater toluene levels produce greater increases in $\mathrm{O}_{3}$.

\subsection{Comparison with observed data}

Ambient monitoring data from the United States Environmental Protection Agency's Air Quality System are used to evaluate mean bias (MB) and mean normalized bias (MNB)
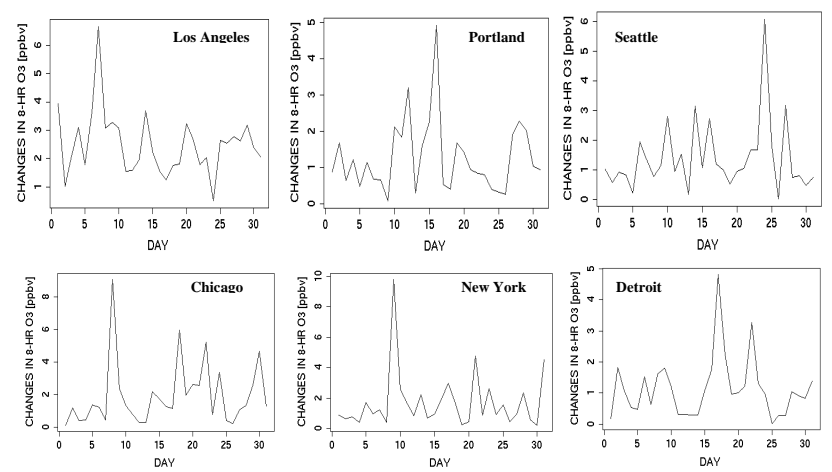

Fig. 6. Day-to-day variation of the increases in daily 8-h maximum $\mathrm{O}_{3}$ in selected areas.

for $\mathrm{O}_{3}$. The median and inter-quartile range of $\mathrm{MB}$ and $\mathrm{MNB}$ for daily maximum 8-h $\mathrm{O}_{3}$ for CB05-TU and CB05-Base are presented in Figs. 7 and 8, respectively. Predicted daily maximum 8- $\mathrm{h} \mathrm{O}_{3}$ levels with $\mathrm{CB} 05-\mathrm{Base}$ are lower than the observed data in Los Angeles and predictions with CB05TU improve the MB and MNB at all observed concentrations. In Portland, Seattle, Chicago, New York/New Jersey, and Detroit $\mathrm{CB} 05-\mathrm{TU}$ increases predicted $\mathrm{O}_{3}$ concentrations for all observed $\mathrm{O}_{3}$ concentrations and decreases $\mathrm{MB}$ and MNB at higher observed $\mathrm{O}_{3}$ concentrations; however, it also marginally increases the $\mathrm{MB}$ and $\mathrm{MNB}$ at lower observed $\mathrm{O}_{3}$ concentrations.

\subsection{4 Impact on ozone production efficiency}

Ozone production efficiency (OPE) is defined as the number of $\mathrm{O}_{3}$ molecules formed from each molecule of $\mathrm{NO}_{\mathrm{x}}$ oxidized to $\mathrm{NO}_{\mathrm{z}}$ and can be calculated from the slope of a regression between $\mathrm{O}_{3}$ and $\mathrm{NO}_{z}$. OPEs are estimated using $\mathrm{O}_{3}$ and $\mathrm{NO}_{\mathrm{z}}$ values during daytime (10:00-05:00 p.m.) and when $\mathrm{O}_{3} / \mathrm{NO}_{\mathrm{x}}$ are greater than 46 (aged air mass) (Arnold et al., 2003). OPE obtained with CB05-TU is marginally lower than the value obtained with $\mathrm{CB} 05$-Base at Los Angeles $(\mathrm{OPE}=5.9$ with $\mathrm{CB} 05-\mathrm{TU}, \mathrm{OPE}=6.3$ with CB05-Base, correlation coefficient $=0.90)$. OPE obtained with CB05-TU is similar to the value obtained with $\mathrm{CB} 05$-Base at Chicago (OPE $=4.1$ with both CB05-TU and CB05-Base, correlation coefficient $=0.79$ ). Increases in $\mathrm{O}_{3}$ with the new mechanism are associated with increased $\mathrm{NO}_{\mathrm{z}}$. Similar changes are obtained for other areas in the western and eastern US. Thus, CB05-TU increases $\mathrm{O}_{3}$ by increasing $\mathrm{NO}_{\mathrm{z}}$ and without enhancing OPE.

\subsection{Impact on ozone control strategy}

While predicted $\mathrm{O}_{3}$ mixing ratios are important for model evaluation, relative reduction factors (RRF) are valuable for developing emissions control strategies. To evaluate RRF, additional model simulations were performed with a $25 \%$ 

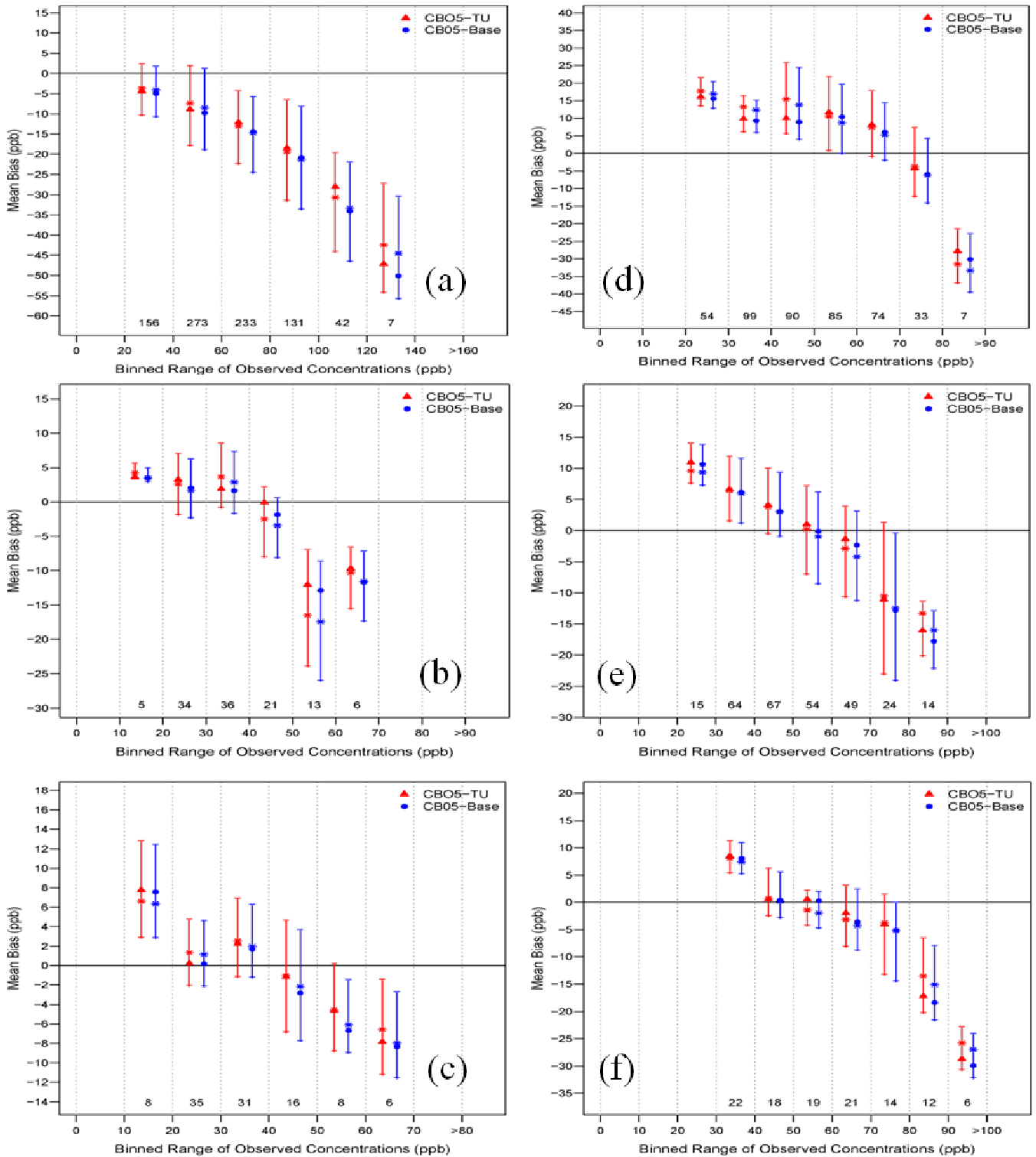

Fig. 7. The median and inter-quartile range of mean bias for the daily maximum 8-h $\mathrm{O}_{3}$ with CB05-TU and CB05-Base: (a) Los Angeles (b) Portland (c) Seattle (d) Chicago (e) New York/New Jersey (f) Detroit. Number beneath each paired evaluation represents the total sample number in each binned range of observed concentration.

reduction in $\mathrm{NO}_{\mathrm{x}}$ emissions using each mechanism. RRF are calculated using results obtained with normal and reduced $\mathrm{NO}_{\mathrm{x}}$ emissions for each mechanism. RRF calculated with CB05-Base are identical to values obtained with CB05-TU for most areas. Only minor changes $(0.01-0.02)$ occur in RRF for some isolated areas. CB05-TU does not change RRF compared to those with CB05-Base; thus it is not expected to affect inferences on air pollution control strategies drawn from the model.

\subsection{Sensitivity of predicted $\mathrm{O}_{3}$ with toluene emissions}

Developing a reliable emissions inventory is a resource intensive process. While tremendous improvements have been made in past years, current emissions inventories still contain large uncertainties (Placet et al., 2000; Sawyer et al., 2000; Werner et al., 2005). To evaluate the sensitivity of predicted $\mathrm{O}_{3}$ to increased toluene emissions, two additional simulations were conducted by doubling toluene emissions $(2 \times$ toluene emissions obtained using NEI). One simulation was conducted using CB05-Base with enhanced 

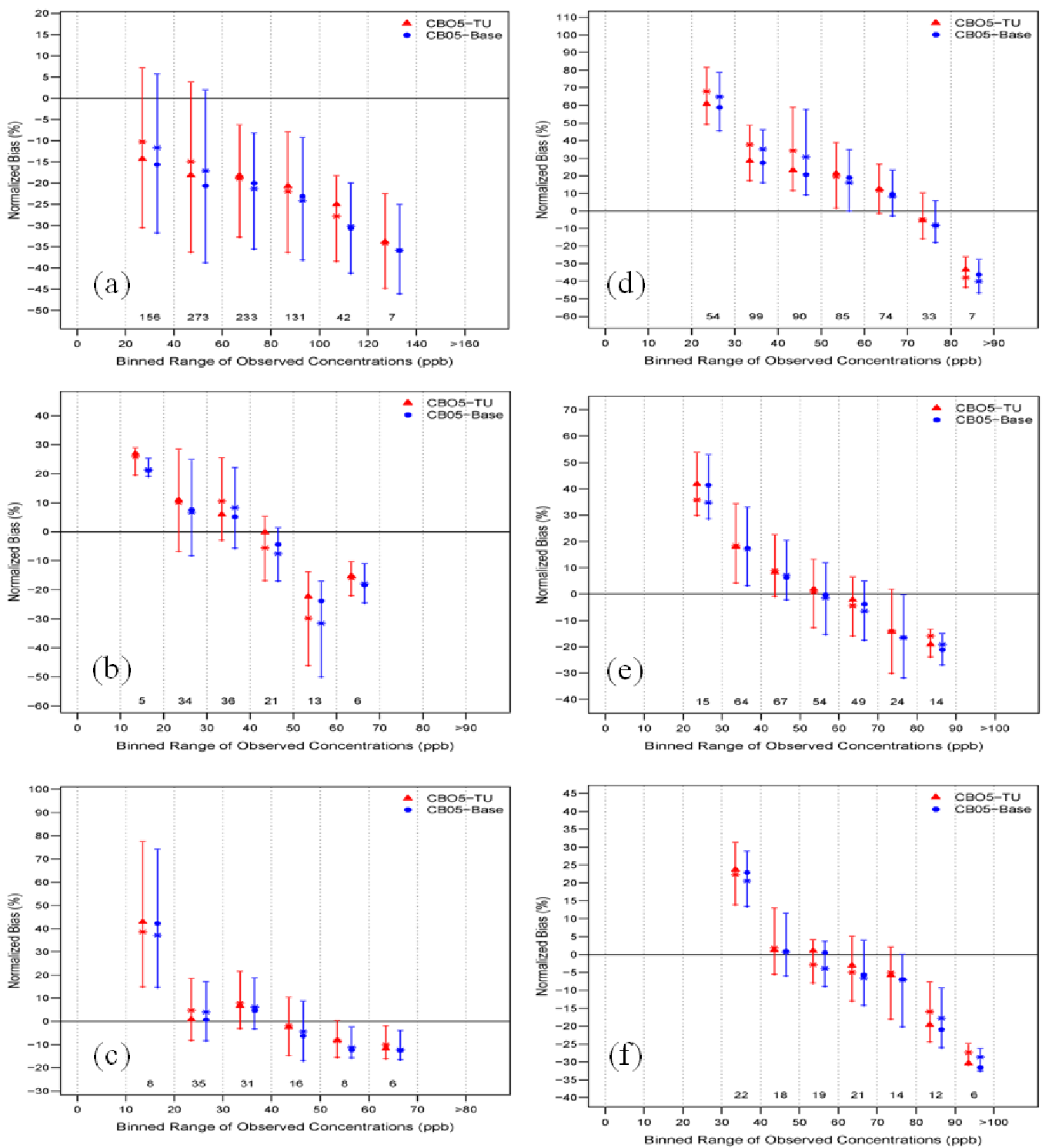

Fig. 8. The median and inter-quartile range of mean normalized bias for the daily maximum 8-h $\mathrm{O}_{3}$ with CB05-TU and CB05-Base: (a) Los Angeles (b) Portland (c) Seattle (d) Chicago (e) New York/New Jersey (f) Detroit. Number beneath each paired evaluation represents the total sample number in each binned range of observed concentration.

toluene emissions and the other simulation was conducted using CB05-TU with enhanced toluene emissions. Larger increases in $\mathrm{O}_{3}$ occur between the two mechanisms with enhanced toluene emissions than those with normal toluene emissions. For example, CB05-TU increases daily maximum 8-h $\mathrm{O}_{3}$ by 9 ppbv in Los Angeles with enhanced toluene emissions compared to an increase of $6 \mathrm{ppbv}$ with normal toluene emissions on July 6. Similarly, CB05-TU increases daily maximum $8-\mathrm{h} \mathrm{O}_{3}$ by $17 \mathrm{ppbv}$ in Chicago with enhanced toluene emissions compared to an increase of $10 \mathrm{ppbv}$ with normal toluene emissions on 8 July. Thus, CB05-TU can produce additional $\mathrm{O}_{3}$ compared to those with $\mathrm{CB} 05$-Base if greater toluene emissions are present which suggests that the new mechanism can be important in areas with elevated toluene emissions.

\subsection{Impact on selected aerosol species}

Monthly mean anthropogenic SOA, biogenic SOA, and incloud SOA with CB05-Base and their percent increases between the two mechanisms are shown in Fig. 9. Predicted anthropogenic SOA concentrations are greater in the eastern US than those in the western US. Concentrations over $0.05 \mu \mathrm{g} \mathrm{m}^{-3}$ are predicted over most areas in the eastern US while such levels are predicted only over smaller areas in 

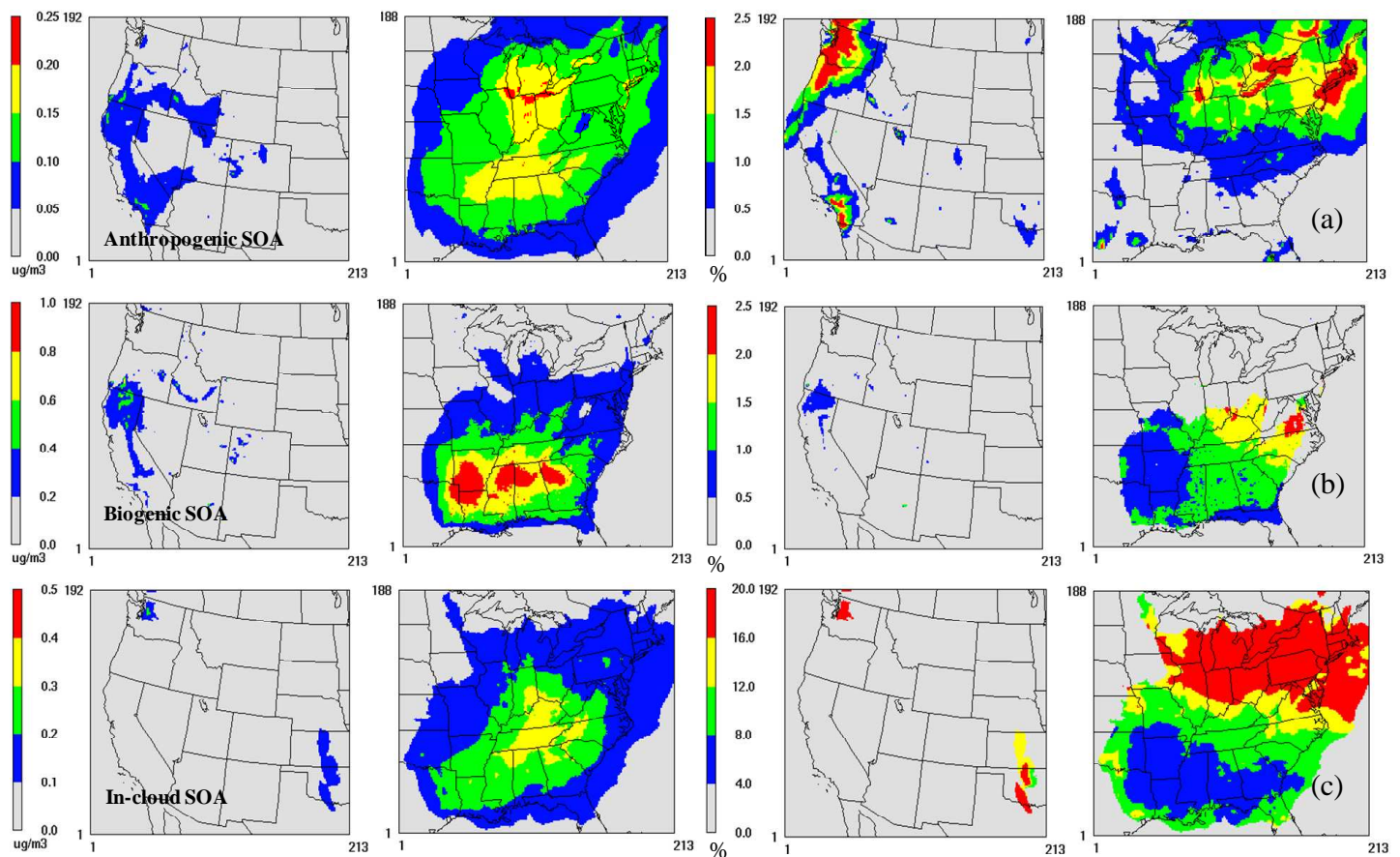

Fig. 9. (a) Monthly mean anthropogenic SOA with CB05-Base and percent increases in mean anthropogenic SOA between CB05-TU and CB05-Base (b) mean biogenic SOA with CB05- Base and percent increases between CB05-TU and CB05-Base (c) mean in-cloud SOA with CB05-Base and percent increases in mean in-cloud SOA between CB05-TU and CB05-Base. In each row, the first two plots represent mean values $\left(\mu \mathrm{g} \mathrm{m}^{-3}\right)$ and the last two plots represent percent changes $(\%)$.

the western US. More anthropogenic VOCs are emitted in the eastern US than in the western US; consequently SOA derived from these precursors are greater in the eastern US. CB05-TU increases anthropogenic SOA by more than $2 \%$ in the northwestern US, Los Angeles, and northeastern US. Carlton et al. (2010) describe SOA formation mechanisms in CMAQv4.7. In CMAQ, benzene, toluene, and xylene (precursors to anthropogenic SOA) react with $\mathrm{OH}$ to produce organic peroxy radicals. These organic peroxy radicals react with NO to produce semi-volatile organic compounds and $\mathrm{HO}_{2}$ to produce non-volatile SOA. Semi-volatile organic compounds produced via the NO reaction pathway can partition to form SOA. Semi-volatile organic compounds can also form non-volatile oligomers through particle phasereactions. While the CB05-TU produces more organic peroxy radicals via reactions of VOCs with enhanced $\mathrm{OH}$, increases in SOA via the NO reaction pathway are small since $\mathrm{NO}$ also decreases with $\mathrm{CB} 05-\mathrm{TU}$. Since $\mathrm{HO}_{2}$ increases with CB05-TU, SOA produced via the $\mathrm{HO}_{2}$ reaction pathway becomes more important and consequently anthropogenic SOA increases. CB05-TU increases anthropogenic SOA in areas with high levels of both anthropogenic SOA precursors and toluene.

Monthly mean biogenic SOA concentrations exceeding $0.4 \mu \mathrm{g} \mathrm{m}^{-3}$ are predicted over the southeastern US while such values are predicted only over a small area covering northern California and southern Oregon. Biogenic SOA precursors are emitted mostly in the southeastern US; consequently SOA derived from these precursors are high in the southeastern US. CB05-TU increases biogenic SOA by more than $1.0 \%$ over a wide area in the southeastern US while increases in the western US are generally lower than $1.0 \%$ and occur only over small areas. In CMAQ, isoprene, monoterpene, and sesquiterpene are precursors to biogenic SOA. For SOA production from isoprene, only reaction with $\mathrm{OH}$ is considered. For SOA production from monoterpene, reactions with $\mathrm{OH}, \mathrm{O}_{3}, \mathrm{O}\left({ }^{3} \mathrm{P}\right)$, and $\mathrm{NO}_{3}$ are considered. For SOA production from sesquiterpene, reactions with $\mathrm{OH}, \mathrm{O}_{3}$, and $\mathrm{NO}_{3}$ are considered. These reactions produce semi-volatile organic compounds which partition to form SOA. The semivolatile organic compounds can also form oligomers through particle phase-reactions. Acid enhanced isoprene SOA is also accounted in the mechanism. Since oxidants increase with CB05-TU, biogenic SOA also increases. Although percent increases in biogenic SOA and anthropogenic SOA are similar, absolute increases of biogenic SOA are much larger. CB05-TU increases biogenic SOA in areas with high levels of both biogenic SOA precursors and toluene.

Monthly mean in-cloud SOA concentrations of greater than $0.2 \mu \mathrm{g} \mathrm{m}^{-3}$ are predicted over a large portion of the eastern US while in-cloud SOA concentrations in the western US are generally lower than $0.2 \mu \mathrm{g} \mathrm{m}^{-3}$ and are predicted only over small isolated areas. In-cloud SOA precursor emissions and cloudiness are more frequent in the eastern US, 

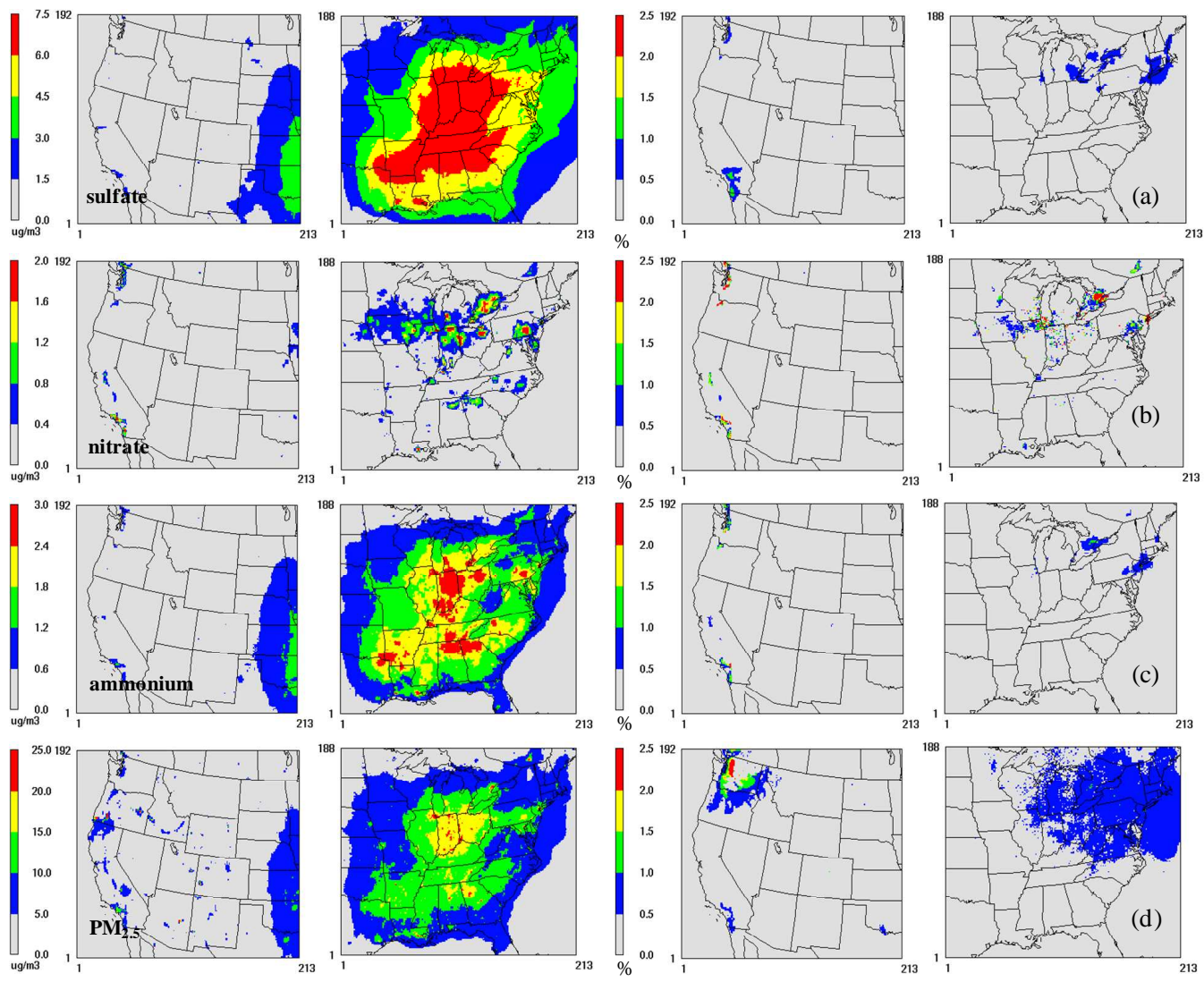

Fig. 10. (a) Monthly mean aerosol sulfate with CB05-Base and percent increase in mean aerosol sulfate between CB05-TU and CB05Base (b) mean aerosol nitrate with CB05-Base and percent increases in mean aerosol nitrate between CB05-TU and CB05-Base (c) mean ammonium with CB05-Base and percent increases in mean ammonium between CB05-TU and CB05-Base (d) mean PM 2.5 with CB05-Base and percent increases in mean $\mathrm{PM}_{2.5}$ between CB05-TU and CB05-Base. In each row, the first two plots represent mean values $\left(\mu \mathrm{g} \mathrm{m}^{-3}\right.$ ) and the last two plots represent percent changes (\%).

thus in-cloud SOA concentrations are high in the eastern US. CB05-TU increases in-cloud SOA by more than $12 \%$ over much of the northeastern US while it increases in-cloud SOA by more than $12 \%$ only over small isolated areas in the western US. Aqueous-phase oxidation of glyoxal and methylglyoxal by $\mathrm{OH}$ produce in-cloud SOA (Carlton et al., 2008, 2010). Glyoxal is not a chemical species in CB05; therefore only methylglyoxal is used for in-cloud SOA production (Carlton et al., 2010). CB05-TU enhances both methylglyoxal and $\mathrm{OH}$; thus in-cloud SOA increases. CB05-TU increases in-cloud SOA in areas of frequent cloud occurrence and high levels of in-cloud SOA precursors and toluene.

The relative contributions of anthropogenic, biogenic, and in-cloud SOA to total SOA with CB05-TU are compared to those with CB05-Base. The relative contribution of anthropogenic SOA with each mechanism ranges up to $54 \%$ in the western US and $39 \%$ in the eastern US. The spatial distribution of the relative contribution of anthropogenic SOA is similar with each mechanism in each domain (the largest difference is $4 \%$ in each domain). The relative contribution of biogenic SOA with each mechanism ranges up to $88 \%$ in the western US and $80 \%$ in the eastern US. The largest difference of the relative contribution of biogenic SOA was $7 \%$ in the western and $4 \%$ in the eastern US. The highest relative contribution of in-cloud SOA increased from $69 \%$ with CB05-Base to $75 \%$ with CB05-TU in the western US and from $46 \%$ with CB05-Base to 52\% with CB05-TU in the eastern US. Thus, the relative contribution of anthropogenic, biogenic, and in-cloud SOA to total SOA did not substantially change between the two mechanisms.

Monthly mean aerosol sulfate, nitrate, ammonium, and total $\mathrm{PM}_{2.5}$ with $\mathrm{CB} 05$-Base and their percent increases with CB05-TU are shown in Fig. 10. CB05-Base predicts relatively low aerosol sulfate $\left(<1.5 \mu \mathrm{g} \mathrm{m}^{-3}\right)$ over most of the western US compared to relatively high predictions $\left(>3.0 \mu \mathrm{g} \mathrm{m}^{-3}\right.$ ) over most of the eastern US. It predicts relatively high aerosol sulfate $\left(>6.0 \mu \mathrm{g} \mathrm{m}^{-3}\right.$ ) over the Ohio valley area in the eastern US while similar concentrations are not predicted in the western US. Predicted values reach up to $1.5-4.5 \mu \mathrm{g} \mathrm{m}^{-3}$ only over a small area in the western US. Sulfur dioxide is emitted mostly in the eastern US, consequently aerosol sulfate is high in the eastern US. CB05-TU 
increases aerosol sulfate by $0.5-1.5 \%$ in small areas in the western US and $0.5-1.0 \%$ in small areas in the eastern US. CB05-TU increases aerosol sulfate in areas with high levels of both sulfur dioxide and toluene.

Predicted mean aerosol nitrate of greater than $0.8 \mu \mathrm{g} \mathrm{m} \mathrm{m}^{-3}$ are predicted over only isolated areas in the western US while similar values are predicted over a much larger area in the eastern US. CB05-TU increases aerosol nitrate by more than $2.0 \%$ in some isolated areas in the western US and larger areas in the eastern US. CMAQ produces aerosol nitrate from the partitioning of $\mathrm{HNO}_{3}$, which is produced via nighttime homogeneous and heterogeneous hydrolysis of dinitrogen pentoxide as well as daytime production via $\mathrm{NO}_{2}+\mathrm{OH}=\mathrm{HNO}_{3}$. The primary reason for the increase in aerosol nitrate is the enhancement of the daytime production of $\mathrm{HNO}_{3}$.

Mean ammonium concentrations of greater than $1.2 \mu \mathrm{g} \mathrm{m}^{-3}$ are predicted over most of the eastern US while similar concentrations are predicted over only small areas in the western US. The spatial distribution of ammonium with CB05-Base follows to that of aerosol sulfate. CB05-TU increases ammonium over only small isolated areas in both the western and eastern US by $0.5-1.0 \%$. Increases in ammonium concentrations with $\mathrm{CB} 05-\mathrm{TU}$ also follow the pattern of the increases in aerosol sulfate. CB05-Base predicts greater than $10.0 \mu \mathrm{g} \mathrm{m}^{-3}$ of $\mathrm{PM}_{2.5}$ in most areas in the eastern US while concentrations are typically lower than $5.0 \mu \mathrm{g} \mathrm{m}^{-3}$ for most of the western US. CB05-TU increases $\mathrm{PM}_{2.5}$ by $0.5-2.5 \%$ in some areas in the western and $0.5-1.0 \%$ in the northeastern US. However, increases over $1.0 \%$ occur in only a few isolated areas in the western US where predicted mean $\mathrm{PM}_{2.5}$ concentrations are generally lower than $5.0 \mu \mathrm{g} \mathrm{m}^{-3}$.

CB05-TU induced changes in predicted PM concentrations arise primarily from differences in atmospheric oxidant levels. Due to lower actinic flux and temperature in winter, atmospheric chemical reactions proceed at slower rates; consequently atmospheric oxidant levels are lower in winter than in summer. Thus, the impact of CB05-TU on secondary aerosols in winter would likely be less than described here.

\section{Summary}

CB05-TU enhances monthly mean daily 8 -h maximum $\mathrm{O}_{3}$ by a maximum of $2.8 \mathrm{ppbv}$ in the western US and $2.0 \mathrm{ppbv}$ in the eastern US. These changes are largely confined to the vicinity of major urban areas. CB05-TU decreases MB at higher observed $\mathrm{O}_{3}$ concentrations, and increases $\mathrm{MB}$ at lower observed $\mathrm{O}_{3}$ concentrations. CB05-TU enhances $\mathrm{OH}$, $\mathrm{HO}_{2}, \mathrm{RO}_{2}$, and $\mathrm{NO}_{\mathrm{z}}$ levels compared to the CB05-Base. While it enhances $\mathrm{O}_{3}$, it does not increase OPE. The use of CB05-TU does not alter RRF; thus, relative to CB05Base it is not expected to alter inferences on air pollution control strategy. Its impact on $\mathbf{P M}_{2.5}$ is small. This study uses relatively coarse horizontal grid spacings since it focuses over a large geographical area. The impact of the new toluene chemistry on air quality modeling results could be more pronounced in areas with higher toluene emissions if finer horizontal grid spacings are used.

Acknowledgements. Although this paper has been reviewed by EPA and approved for publication, it does not necessarily reflect EPA's policies or views.

Edited by: A. Lauer

\section{References}

Appel, K. W., Gilliland, A. B., Sarwar, G., and Gilliam, R. C.: Evaluation of the Community Multiscale Air Quality (CMAQ) model version 4.5: Sensitivities impacting model performance Part IOzone, Atmos. Environ., 41, 9603-9615, 2007.

Arnold, J. R., Dennis, R. L., and Tonnesen, G. S.: Diagnostic Evaluation of Numerical Air Quality Models with Specialized Ambient Observations: Testing the Community Multiscale Air Quality Modeling System (CMAQ) at Selected SOS 95 Ground Sites, Atmos. Environ., 37, 1185-1198, 2003.

Binkowski, F. S. and Roselle, S. J.: Community Multiscale Air Quality (CMAQ) model aerosol component, I: Model description, J. Geophys. Res., 108(D6), 4183, doi:10.1029/2001JD001409, 2003.

Byun, D. and Schere, K. L.: Review of the governing equations, computational algorithms, and other components of the Models3 Community Multiscale Air Quality (CMAQ) modeling system, Appl. Mech. Rev., 59, 51-77, 2006.

Calvert, J. G., Atkinson, R., Becker, K. H., Kamens, R. M., Seinfeld, J. H., Wallington, T. J., and Yarwood, G.:. The mechanisms of atmospheric oxidation of aromatic hydrocarbons, Oxford University Press, New York, 566 pp., 2002.

Carlton, A. G., Turpin, B. J., Altieri, K. E., Seitzinger, S. P., Mathur, R., Roselle, S. J., and Weber, R. J.: CMAQ model performance enhanced when in-cloud SOA is included: comparisons of OC predictions with measurements, Environ. Sci. Technol., 42(23), 8798-8802, 2008.

Carlton, A. G., Bhave, P. V., Napelenok, S. L., Edward, E. O., Sarwar, G., Pinder, R. W., Pouliot, G. A., and Houyoux, M.: Model representation of secondary organic aerosol in CMAQv4.7, Environ. Sci. Technol., 44(22), 8553-8560, 2010.

Carter, W. P. L.: Implementation of the SAPRC-99 chemical mechanism into the Models-3 Framework, report to the United States Environmental Protection Agency, available at: http://www.cert. ucr.edu/ $\sim$ carter/absts.htm\#s99mod3 (last access: 16 February 2011), 2000.

Eder, B. and Yu, S.: A performance evaluation of the 2004 release of Models-3 CMAQ, Atmos. Environ., 40, 4811-4824, 2006.

Faraji, M., Kimura, Y., McDonald-Buller, E., and Allen, D.: Comparison of the carbon bond and SAPRC photochemical mechanisms under conditions relevant to southeast Texas, Atmos. Environ., 42, 5821-5836, 2008.

Finlayson-Pitts, B. J. and Pitts Jr., J. N.: Chemistry of the Upper Lower Atmosphere, Theory, Experiments and Applications, Academic Press, San Diego, 2000. 
Foley, K. M., Roselle, S. J., Appel, K. W., Bhave, P. V., Pleim, J. E., Otte, T. L., Mathur, R., Sarwar, G., Young, J. O., Gilliam, R. C., Nolte, C. G., Kelly, J. T., Gilliland, A. B., and Bash, J. O.: Incremental testing of the Community Multiscale Air Quality (CMAQ) modeling system version 4.7, Geosci. Model Dev., 3, 205-226, doi:10.5194/gmd-3-205-2010, 2010.

Gery, M. W., Whitten, G. Z., Killus, J. P., and Dodge, M. C.: A photochemical kinetics mechanism for urban and regional scale computer modeling, J. Geophys. Res., 94(D10), 12925-12956, 1989.

Grell, G., Dudhia, J., and Stauffer, D.: A description of the fifthgeneration Penn State/NCAR Mesoscale model (MM5), NCAR Tech. Note NCAR/TN-398+STR, 1994.

Heiden, A. C., Kobel, K., Komenda, M., Koppmann, R., Shao, M., and Wildt, J.: Toluene emissions from plants, Geophys. Res. Lett., 26(9), 1283-1286, 1999.

Placet, M., Mann, C. O., Gilbert, R. O., and Neifer, M. J.: Emissions of ozone precursors from stationary sources: a critical review, Atmos. Environ., 34, 2183-2204, 2000.

Pleim, J. E.: A combined local and nonlocal closure model for the atmospheric boundary layer, Part I: Model description and testing, J. Appl. Meteor. Climatol., 46, 1383-1395, 2007.

Sarwar, G., Luecken, D., Yarwood, G., Whitten, G., and Carter, B.: Impact of an updated Carbon Bond mechanism on air quality using the Community Multiscale Air Quality modeling system: preliminary assessment, J. Appl. Meteorol. Clim., 47, 3-14, 2008.

Sawyer, R. F., Harley, R. A., Cadle, S. H., Norbeck, J. M., Slott, R., and Bravo, H. A.: Mobile sources critical review: 1998 NARSTO assessment, Atmos. Environ., 34, 2161-2181, 2000.
Schwede, D., Pouliot, G., and Pierce, T.: Changes to the biogenic emissions inventory system version 3 (BEIS3), 4th Annual CMAS Models-3 Users' Conference, September 26-28 2005, UNC-Chapel Hill, NC, available at: http://www.cmascenter. org/conference/2005/abstracts/2_7.pdf (last access: 16 February 2011), 2005.

Werner, A., Frey, C. Haneke, B., Zheng, J., and Pennell, W.: Strengths and weaknesses of current emissions inventories, Improving emissions inventories for effective air quality management across North America, NARSTO-05-001 (available at: http://www.narsto.com), 145-152, 2005.

White, M. L., Russo, R. S., Zhou, Y., Ambrose, J. L., Haase, K., Frinak, E. K., Varner, R. K., Wingenter, O. W., Mao, H., Talbot, R., and Sive, B. C.: Are biogenic emissions a significant source of summertime atmospheric toluene in the rural Northeastern United States?, Atmos. Chem. Phys., 9, 81-92, doi:10.5194/acp9-81-2009, 2009.

Whitten, G. Z., Heo, G., Kimura, Y., McDonald-Buller, E., Allen, D., Carter, W. P. L., and Yarwood, G.: A new condensed toluene mechanism for Carbon Bond: CB05-TU, Atmos. Environ., 44, 5346-5355, 2010.

Yarwood, G., Rao, S., Yocke, M., and Whitten, G.: Updates to the carbon bond chemical mechanism: CB05. Final report to the US EPA, RT-0400675, available at: www.camx.com (last access: 16 February 2011), 2005.

US Environmental Protection Agency: locating and estimating air emissions from sources of toluene, EPA-454/R-93-047, Research Triangle Park, NC, available at: http://www.epa.gov/ttnchie1/le/ toluene.pdf (last access: 16 February 2011), March 1994. 